五八九

錄抄誌雜會笢研事醫堂天順

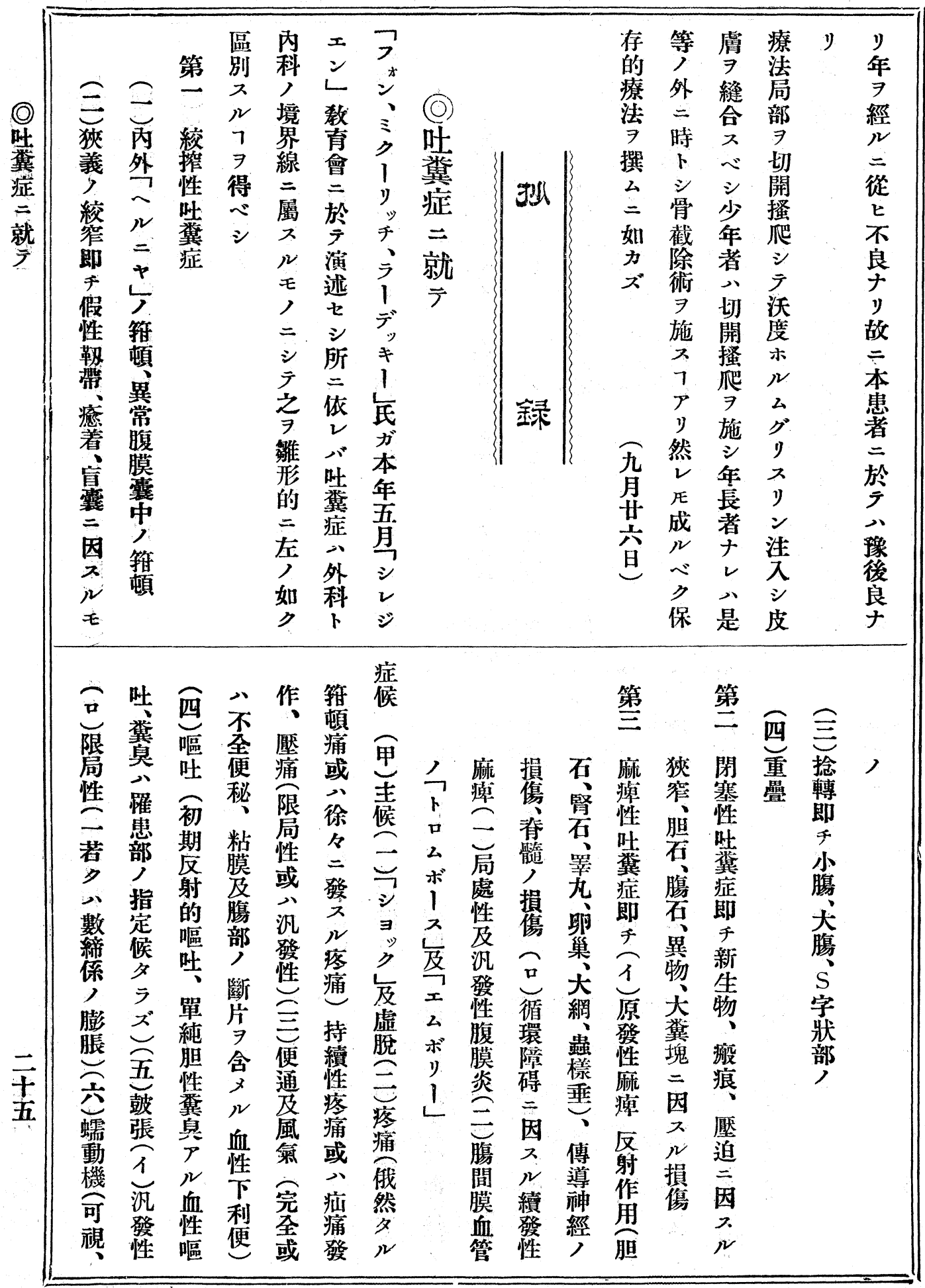


亲八九

中枀術 E便症阿 $\ni$ 治經

死名七時通 $\ni$ 片 區療要過力症乲乙腫可

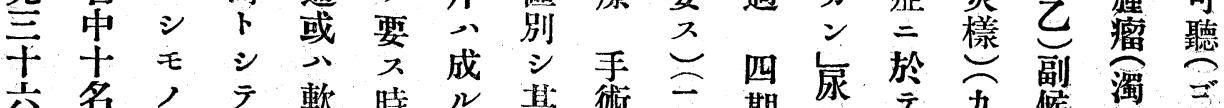

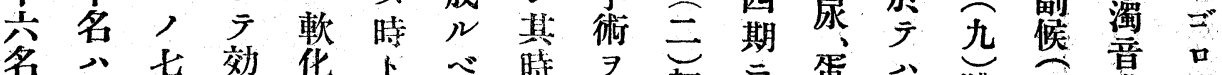

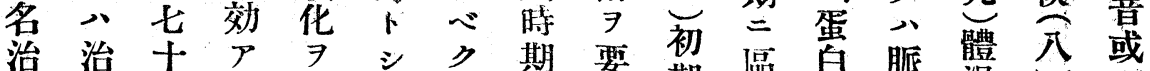

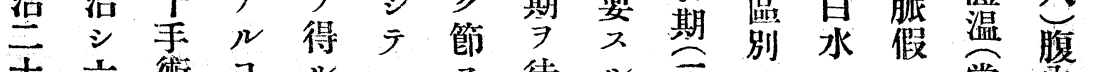

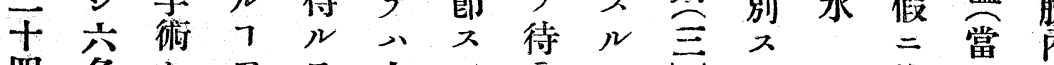

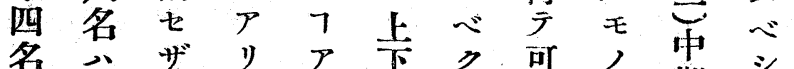

名

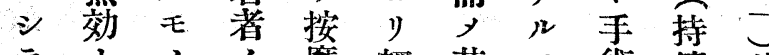

テナノノ摩 輕 其モ 術續 前

其》士梦法壓之,

不平空料

良手名莯大少用宜方票

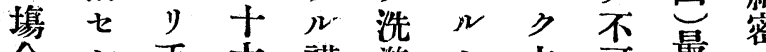

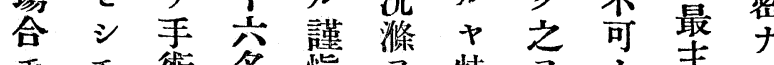

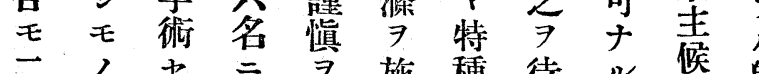

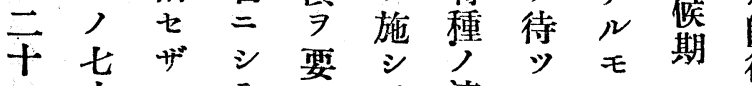

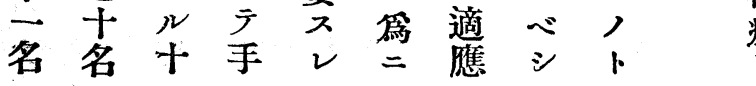

佳 當 两

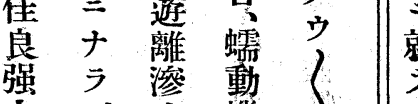

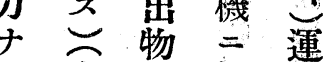

古恩 動

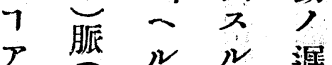

帟 二 抗 速

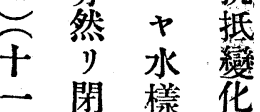

二塞 或 㧼 䉪

1 性

チ翼膜 臭

左走着界人健 邓 各境可發細 オ

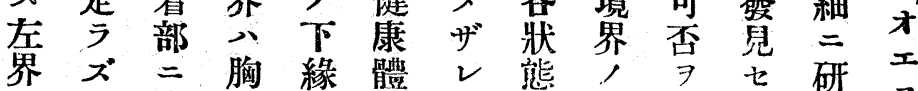

八シ 達 骨

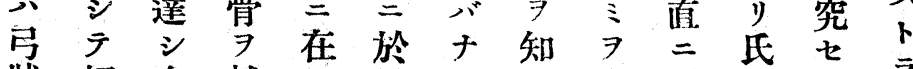

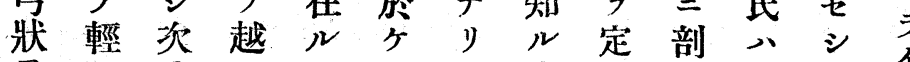

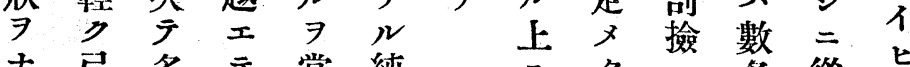

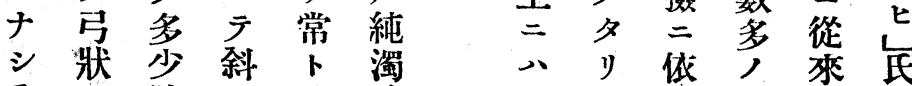

テ $\ni$ 肺 $=$ 音

心ナ肝右 是 部

尖 江界下

二右 $\exists$ 方 $y$ 最

至上地 三左卡

方本 走右 點

左 $==y, ~ 八$

上四屈第境胸

方二曲五 界骨

心

的ナ照二詔

濁 バ 照

二 シ ス 右 $心=$

音部分但系方從

～經 氏 統 點 來

凸 テ通胡直接

定 驗 八的 二

左 常骨二法

厂 下 $\longrightarrow$, 第

右方直胸行 四

下二線骨 ス䏚

厶 二單打於心

方凸二附右骨

ル從二馀方臟

>一純法異打

必心濁 $\ni 广$ 診

要心音試 $心$ 法

藏部ミ7

認ノノ其 $尹$ 精

\&

(2) $\quad \stackrel{0}{0}$ 初

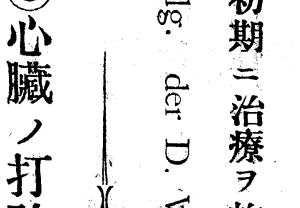

悹施

七

テ就管

의 $\pi$

边

望 $\frac{\text { 辛 }}{\text { 亲 }}$

E

モ

F

.

$\neq$ 
七八九錄抄誌雜會究研事醫堂天順

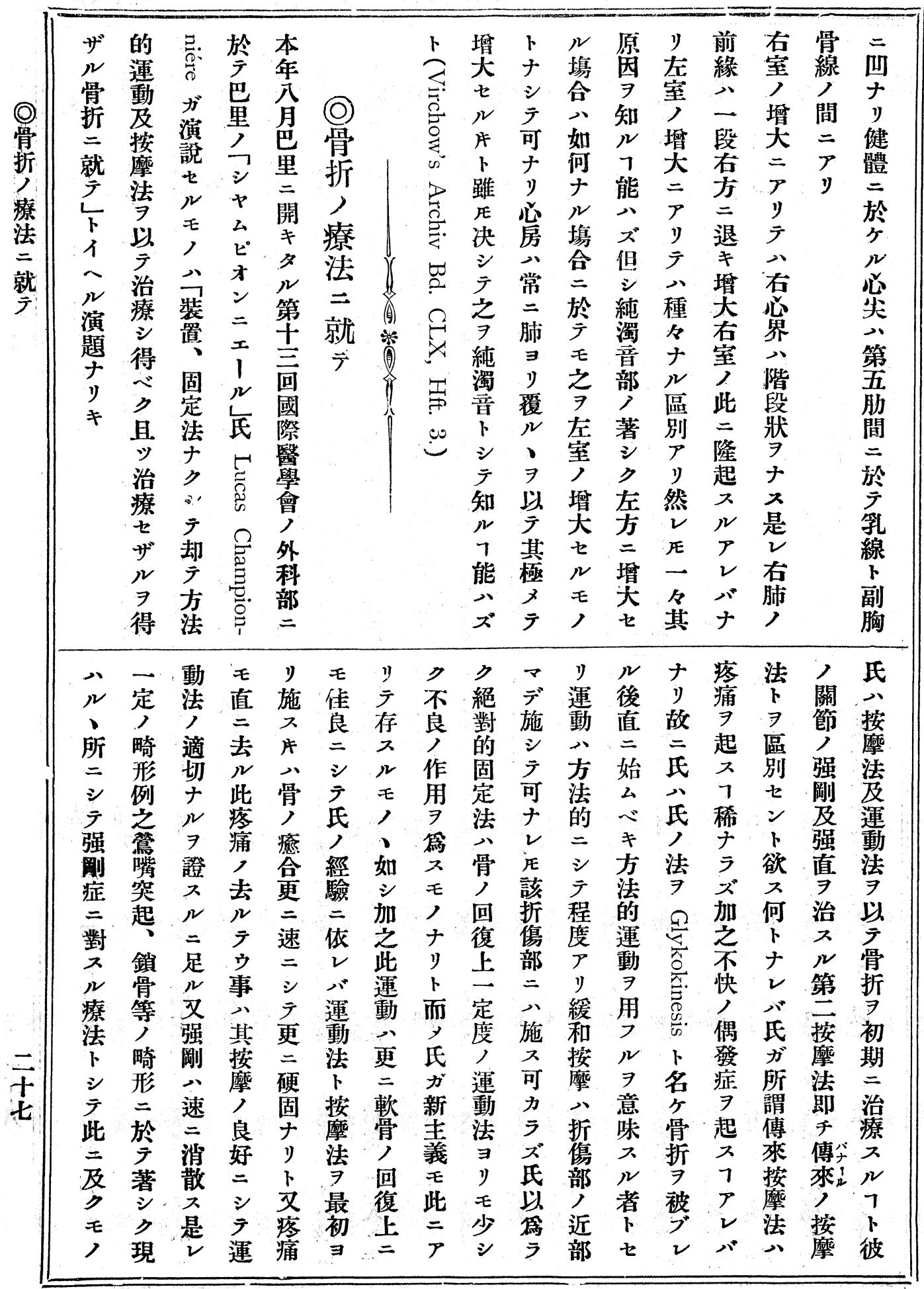




\section{號三十三百三第誌雜會究研事醫堂天順 八八九}

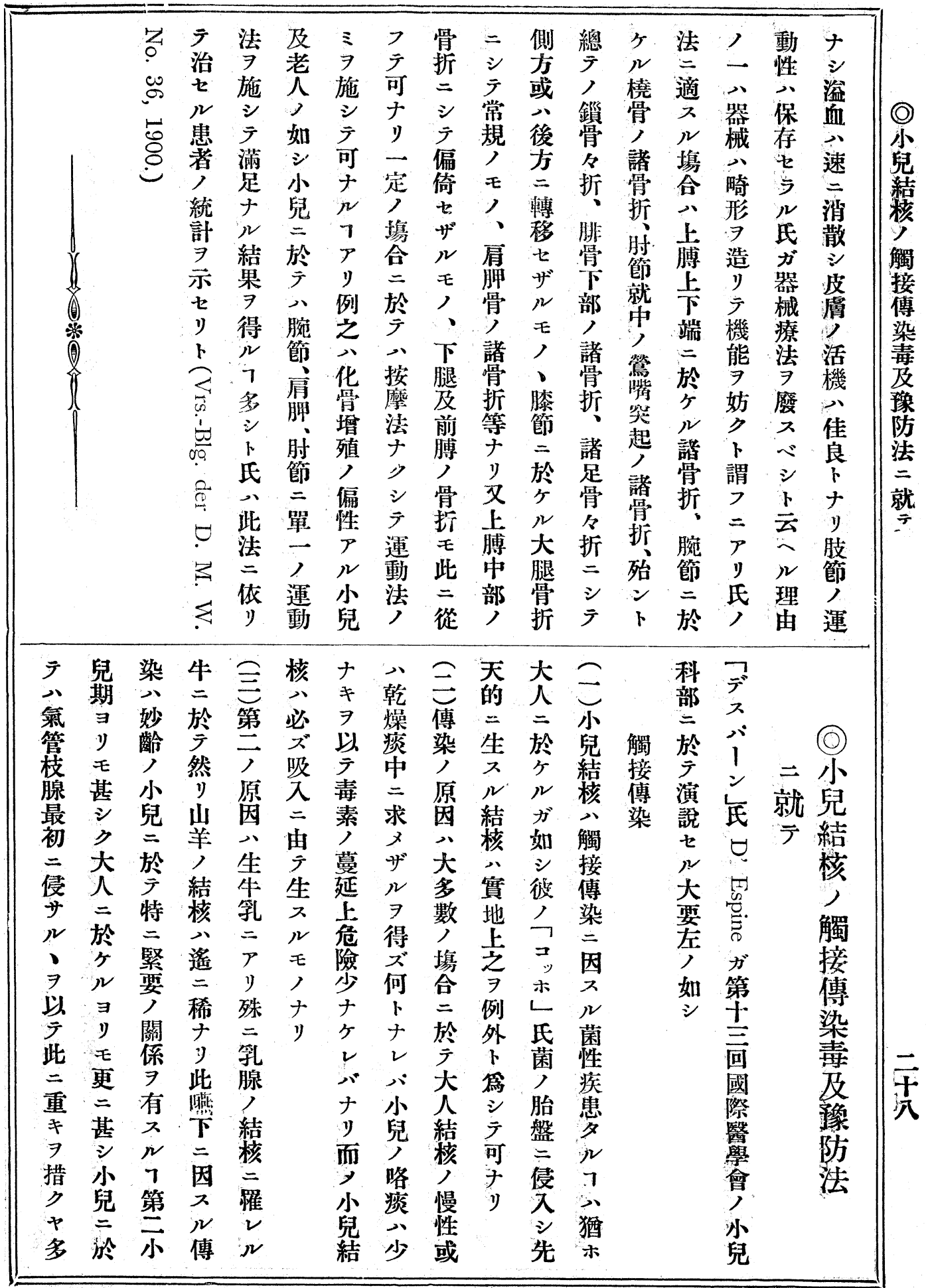




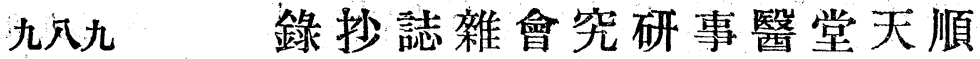

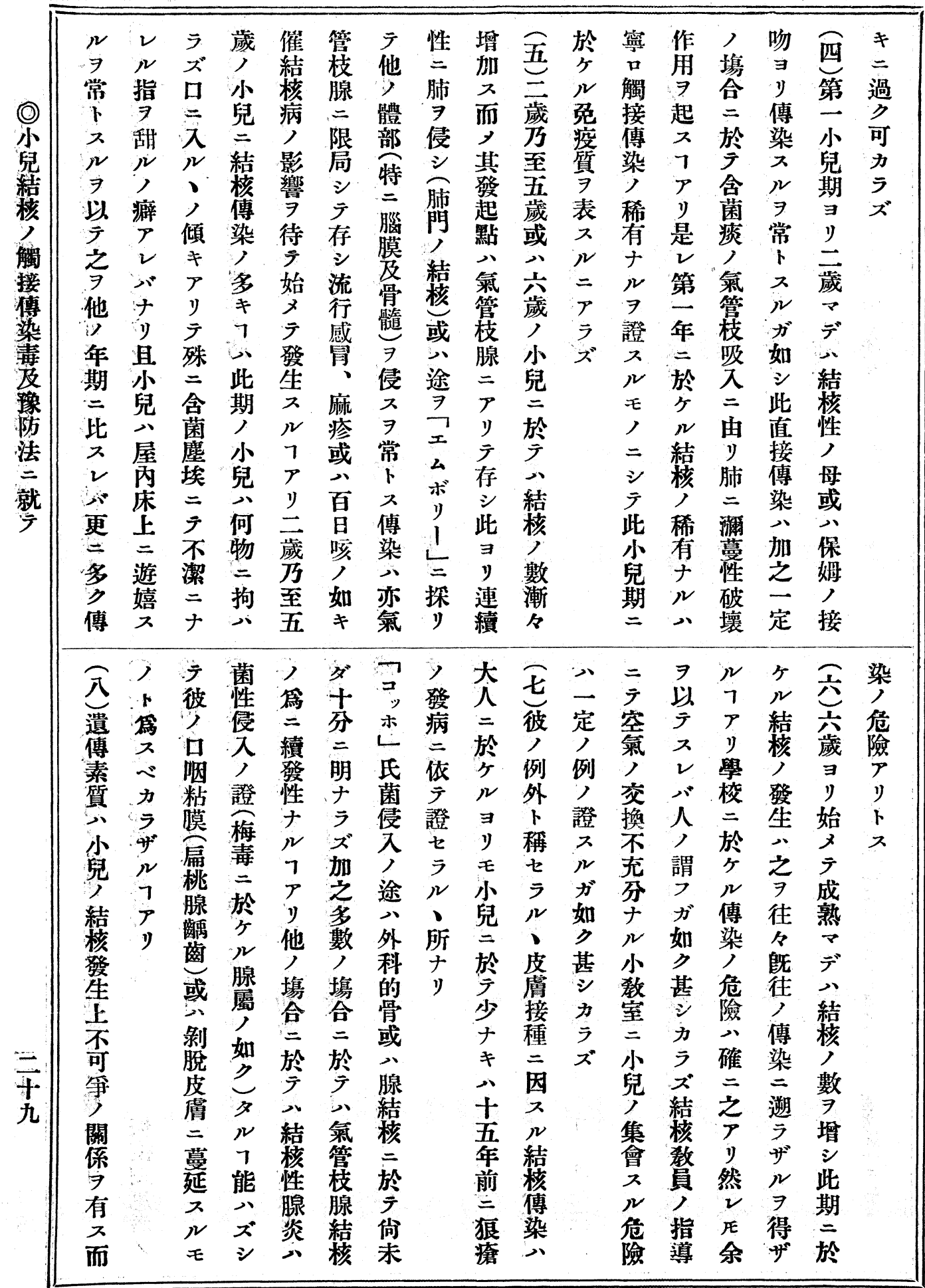




\section{號三十三百三第誌雜會究研事醫堂天順 O九九}

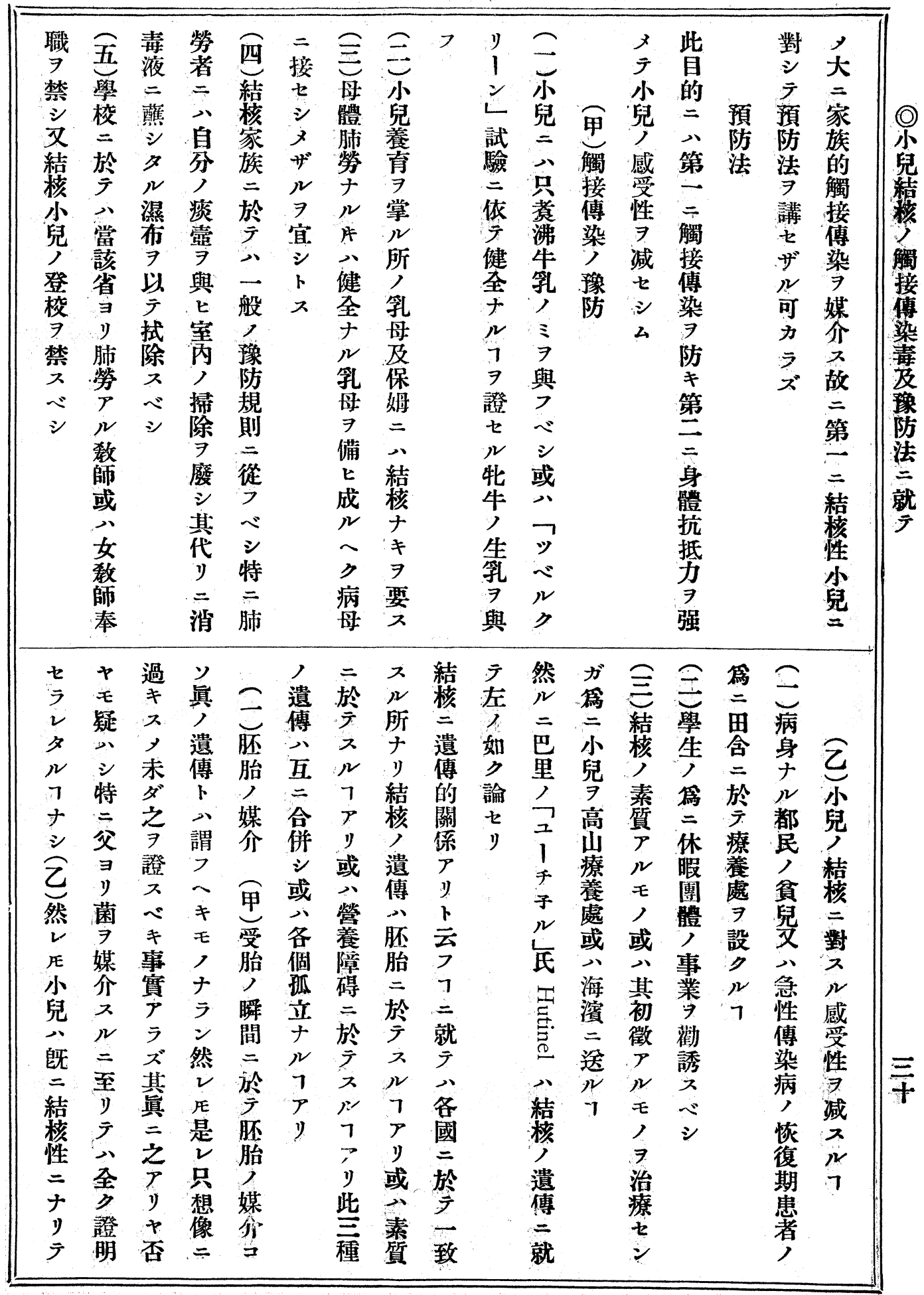




\section{乎九杂錄抄誌雜會究"研事醫堂天順}

(a)

小

結

核

觸

接

傅

染

毒

稳

法

就

第

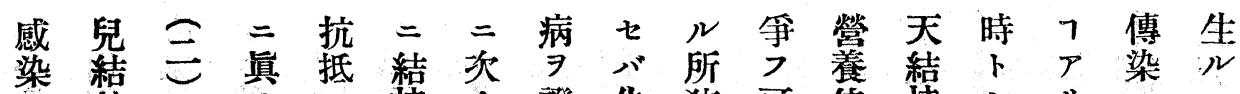

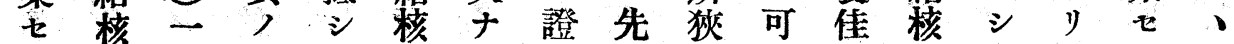

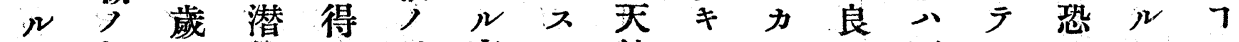

马 初以候

穴期内性ジ 二解小 小 $、$ 依常極遺肺三八限盤り 證剖兒 只

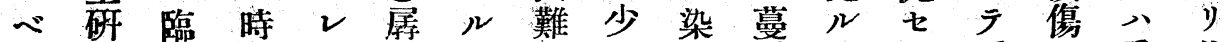
キ 究床停 ザ弱可子ナノ长べル看二重此

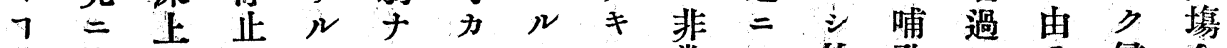
佊結七フルラフコ常モモ故孔セう侵合

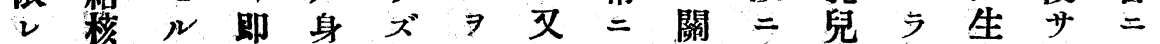

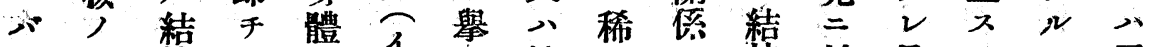

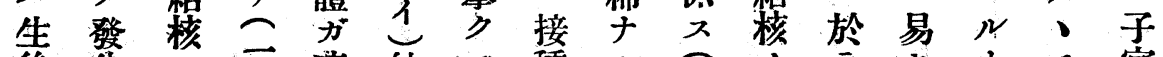

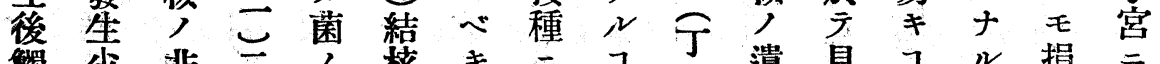

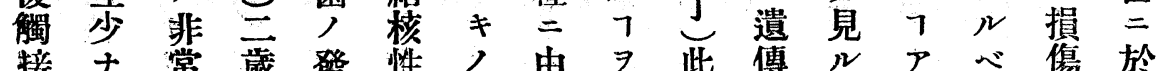

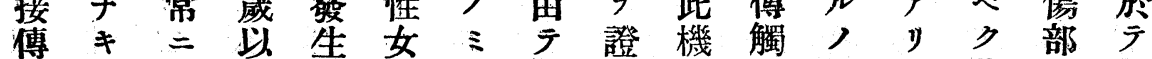

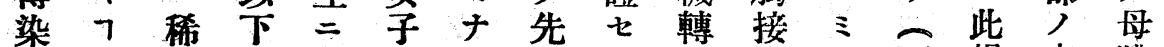

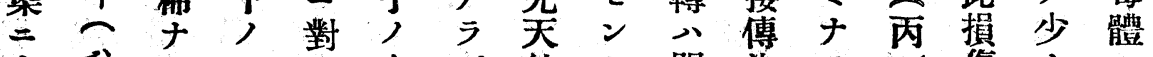

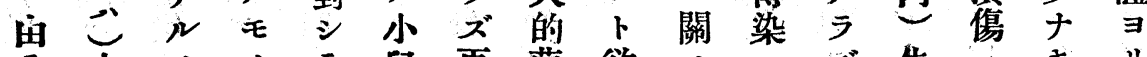

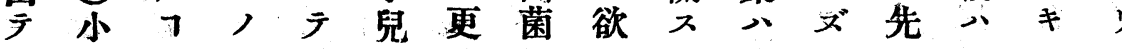

八: 菌: 应遺》核有發得二核，此

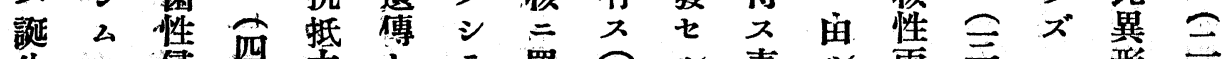

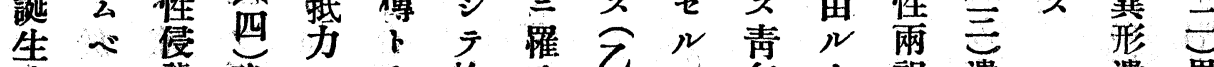

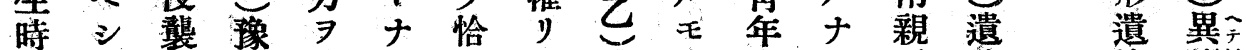

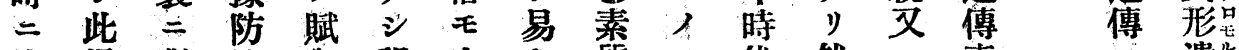
傳 保 對法 興租小 $\neq$ 質 $=$ 代然 染護 シ 七先兒, 方, 方其質 y傳

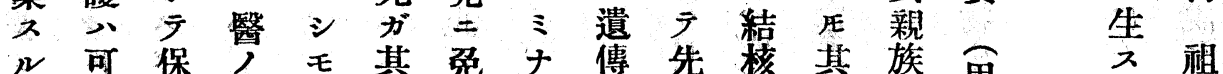
能護厓, 尒疫

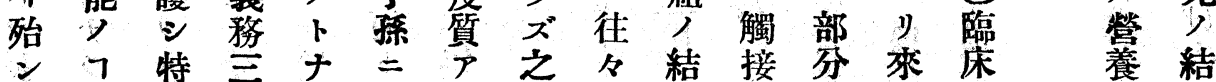
$卜$ 小 $=\vec{P}$ 同 $心$ 疾核傳 $心$ 不核

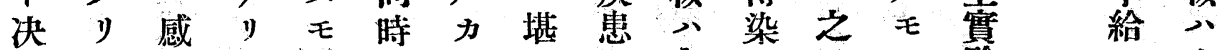
シ 何 染 2 可 $=$,

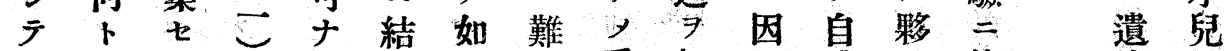

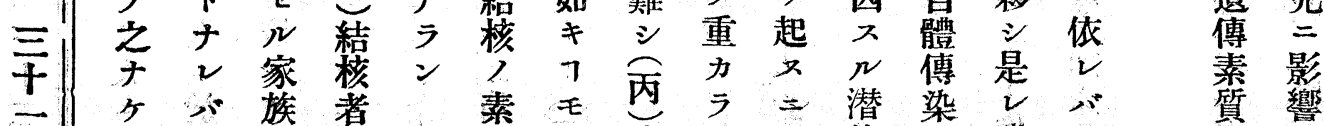

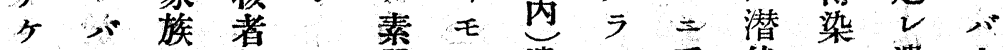
レ肺ノ 質 ア遺シ重伏 二遺小

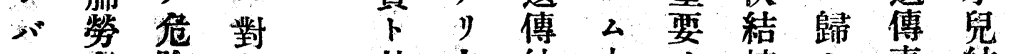

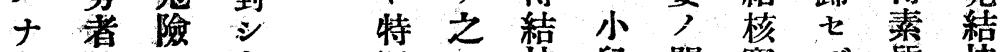
y 3 小 别 $\ni$ 核兒關䇫ザ質核 此小避兒 ナ混 八係 $⿻ コ 一$

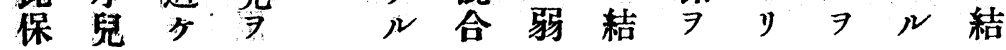
質 響 卜 又 混 $N$ 同 7 大 明 ○ 力 


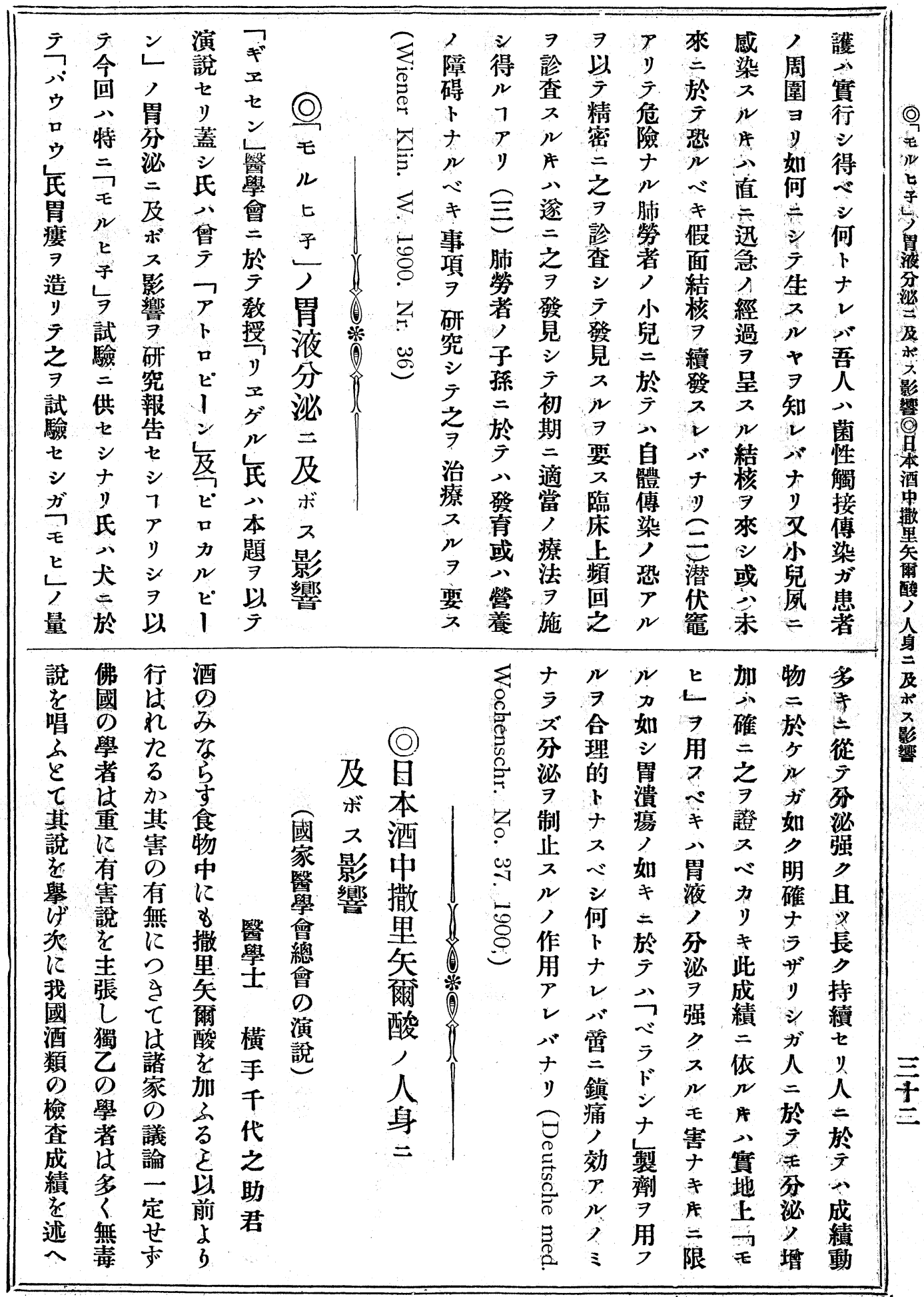


三九九錄抄誌雜會究研事醫堂天順

\begin{tabular}{|c|c|c|c|c|c|c|c|c|c|c|c|c|c|c|c|c|}
\hline 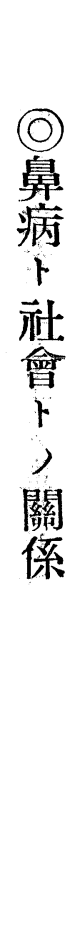 & 每 & 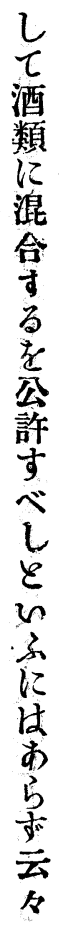 & 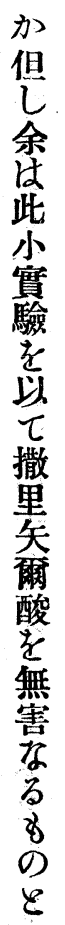 & 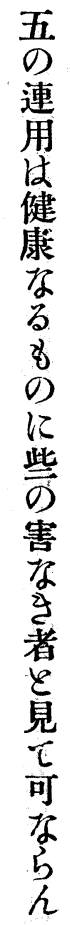 & 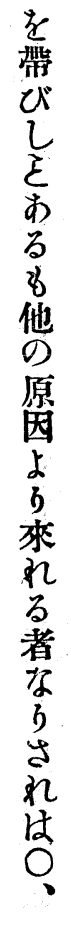 & 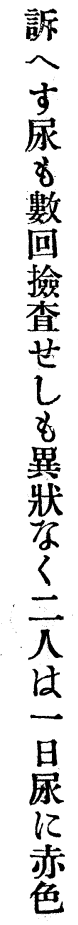 & 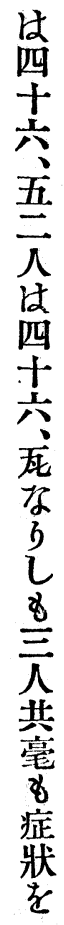 & 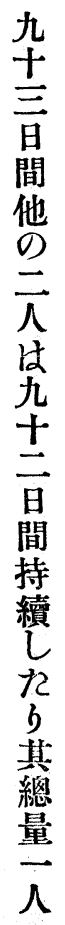 & 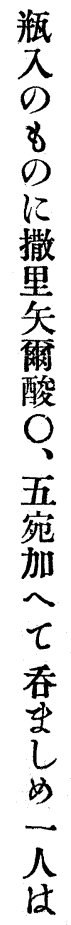 & 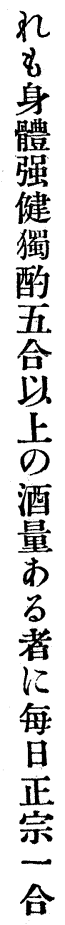 & 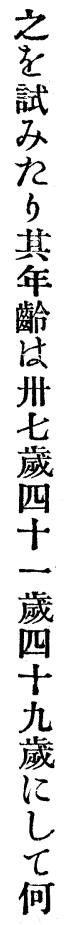 & 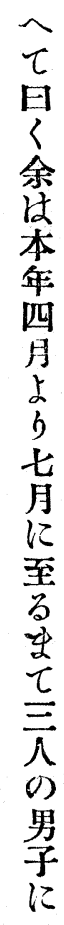 & 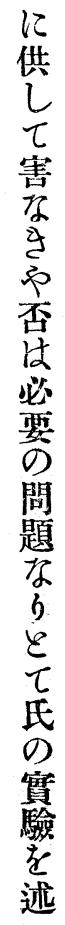 & 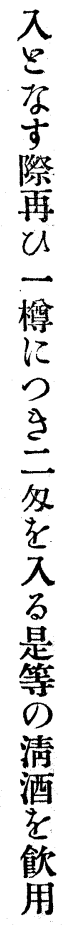 & 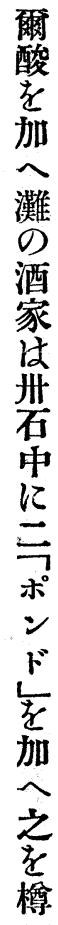 & 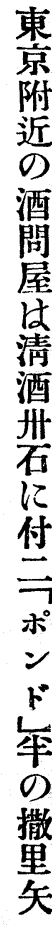 \\
\hline 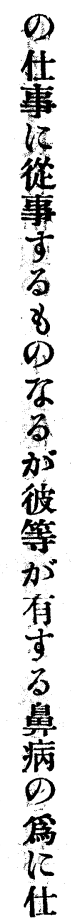 & 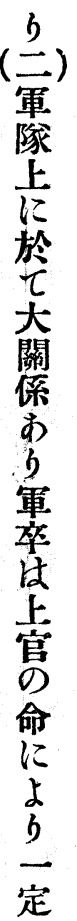 & 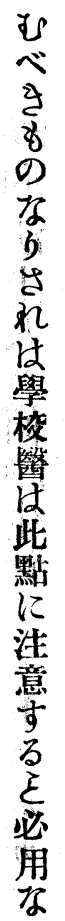 & 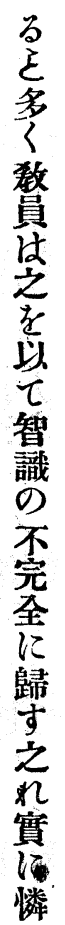 & 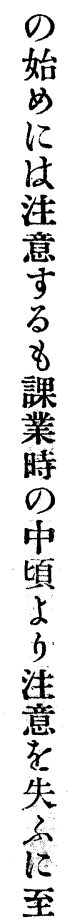 & 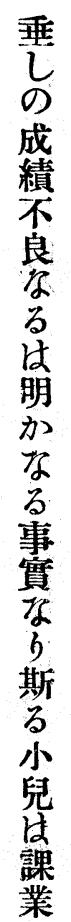 & 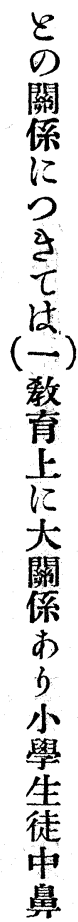 & 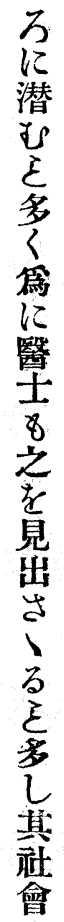 & 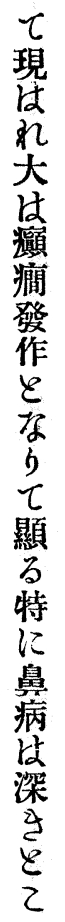 & 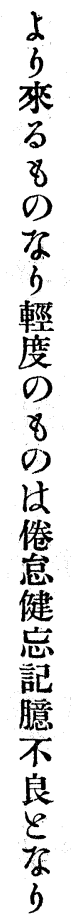 & 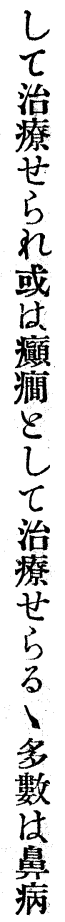 & 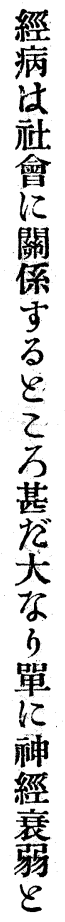 & 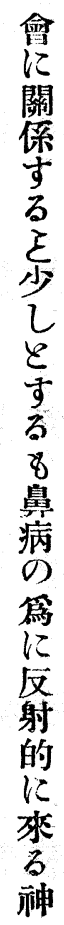 & 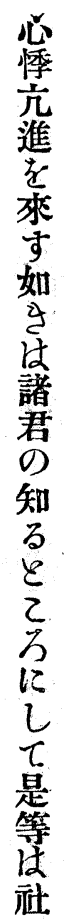 & 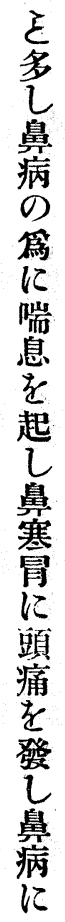 & 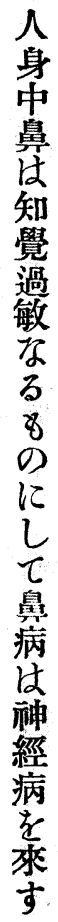 & $\begin{array}{l}\text { 岡 } \\
\text { 田 } \\
\text { 和 } \\
\text { 一 } \\
\text { 郎 } \\
\text { 君 }\end{array}$ \\
\hline
\end{tabular}


號三十三百三第誌雜會究研事醫堂天順

四九九

\begin{tabular}{|c|c|c|c|c|c|c|c|c|c|c|c|c|c|c|c|c|}
\hline 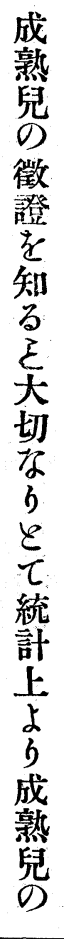 & 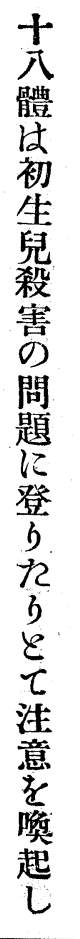 & 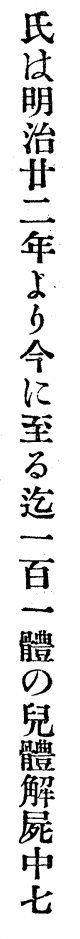 & $\begin{array}{l}\text { 贀 } \\
\text { 士 } \\
\text { 高 } \\
\text { 山 } \\
\text { 正 } \\
\text { 雄 }\end{array}$ & $\begin{array}{l}\text { (0) } \\
\text { 我 } \\
\text { 國 } \\
⿱ 亠 䒑 \\
\text { 於 } \\
\text { ち } \\
\text { 几 } \\
\text { 成 } \\
\text { 熟 } \\
\text { 兒 } \\
\text { 徵 } \\
\text { 證 }\end{array}$ & 䊓 & 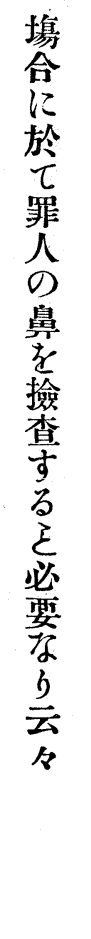 & 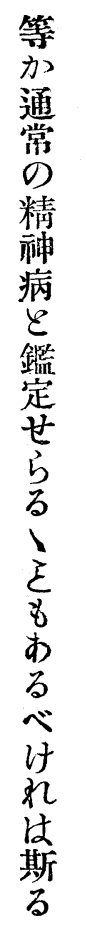 & 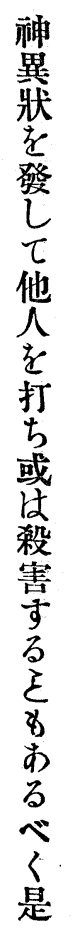 & 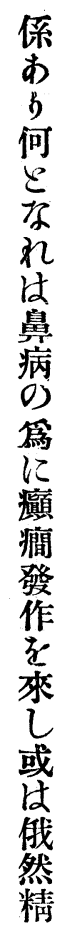 & 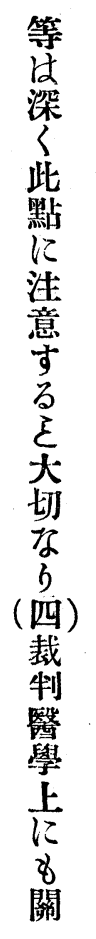 & 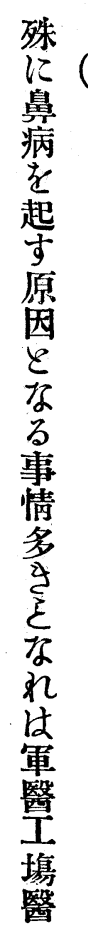 & 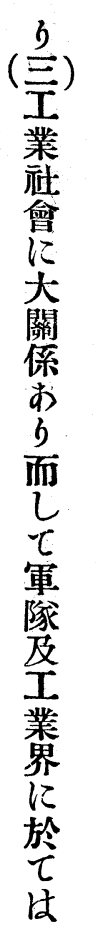 & 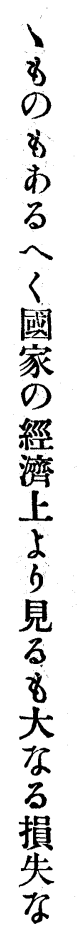 & 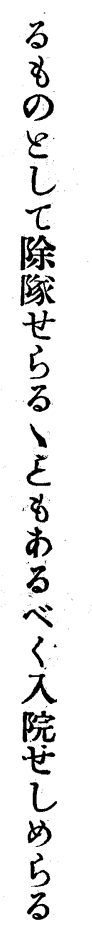 & 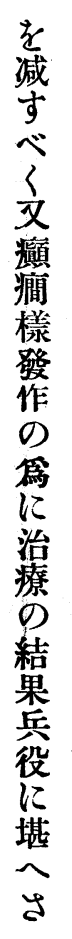 & 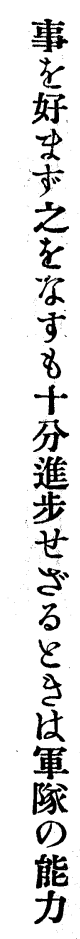 \\
\hline 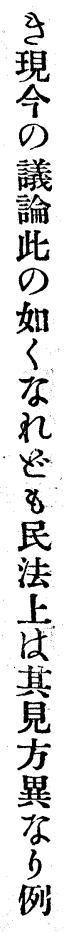 & 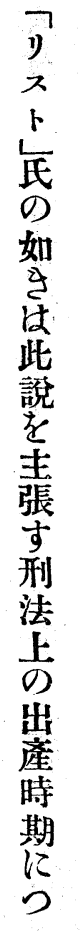 & 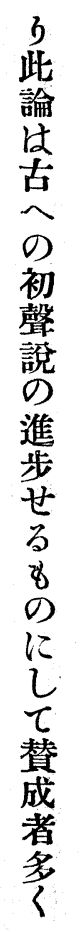 & 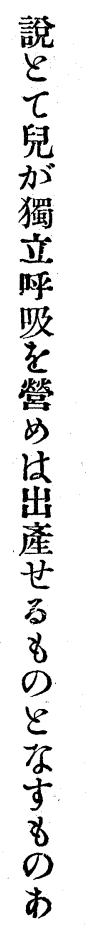 & 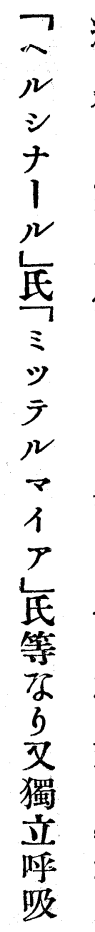 & 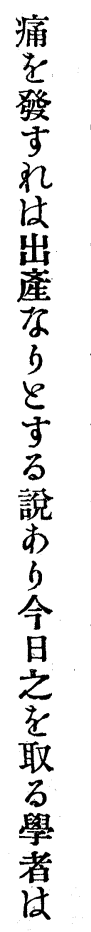 & 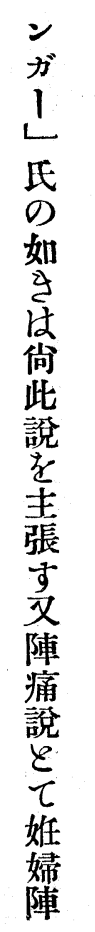 & 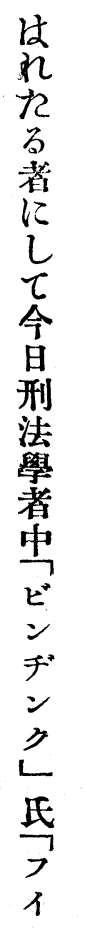 & 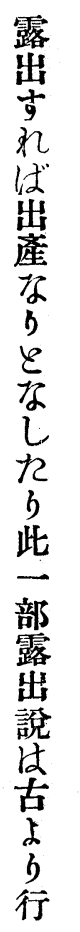 & 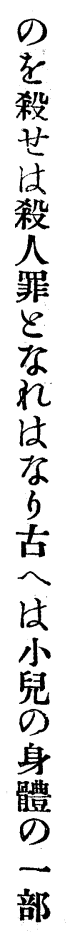 & 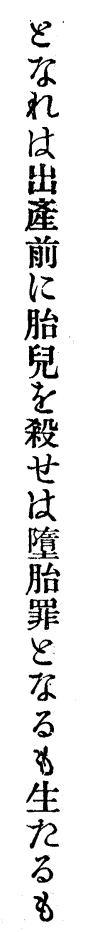 & 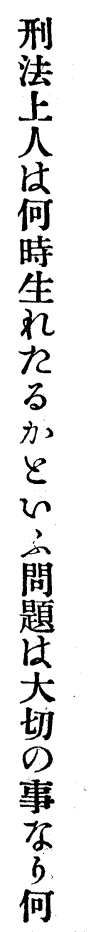 & $\begin{array}{l}\text { 岡 } \\
\text { 田 } \\
\text { 朝 } \\
太 \\
\text { 郎 } \\
\text { 君 }\end{array}$ & $\begin{array}{c}\text { 何 } \\
\text { 時 } \\
\text { ヨ } \\
\text { リ } \\
\text { 刑 } \\
\text { 法 } \\
\text { 上 } \\
\text { 責 } \\
\text { 稚 } \\
\text { 尹 } \\
\text { 員 } \\
\text { フ } \\
\text { 心 } \\
\text { キ } \\
\text { ヤ }\end{array}$ & 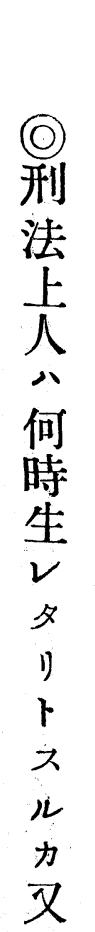 & 每 & 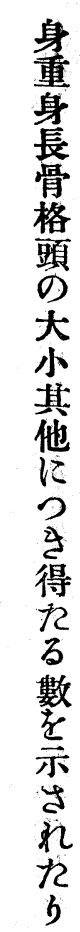 \\
\hline
\end{tabular}


()

刑

法

卡



何

趎

生

夕

$y$

ז

간

吕

桑

時

寻

刑

法

,

責

隽

角

ᄀ

キ

†

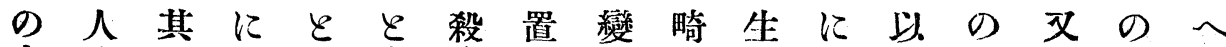

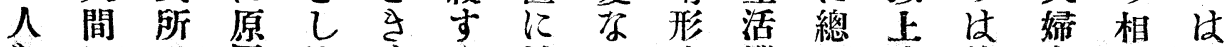

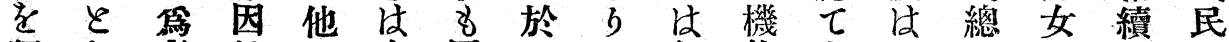
獨し 者結に大同 $\tau \varepsilon$ 如能人其 $\tau$ 婎著法

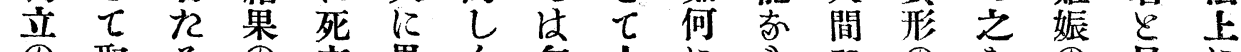

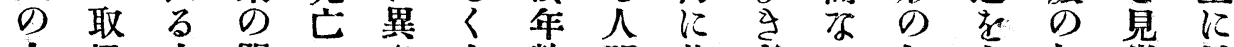

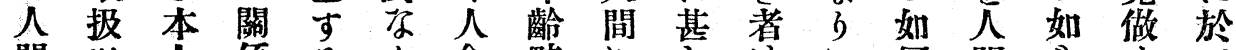
間

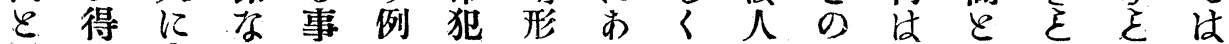

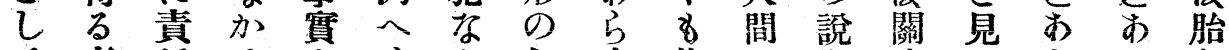
$\tau$ 者任る

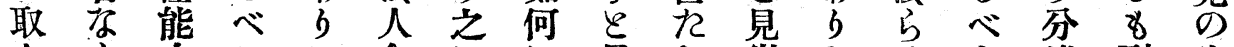

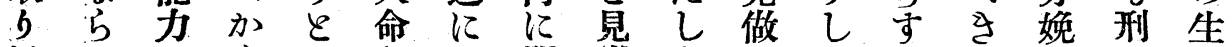

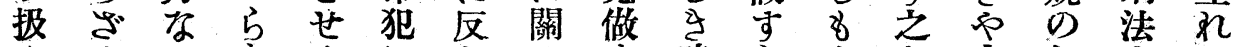

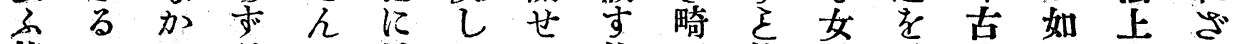

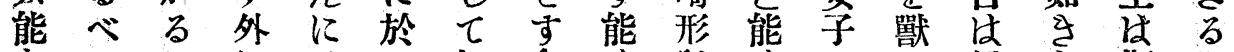

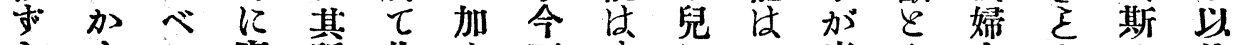

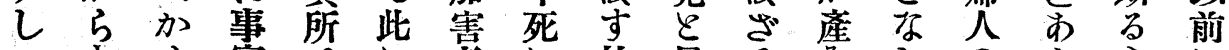

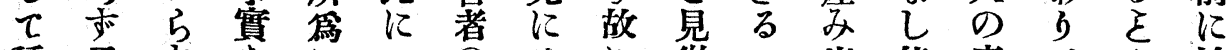

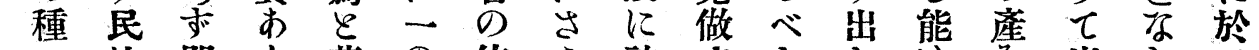
々 法即 5 落 9 位 5 被

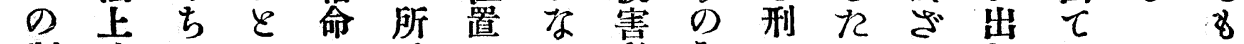

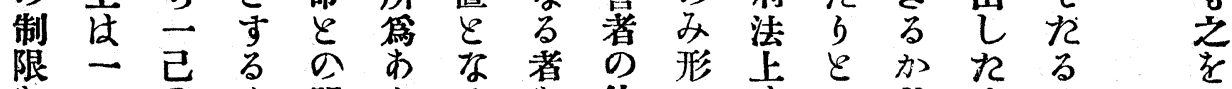

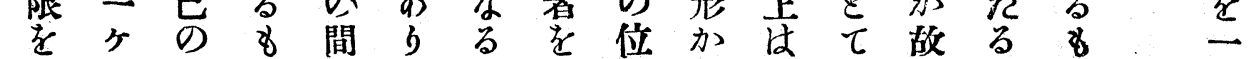

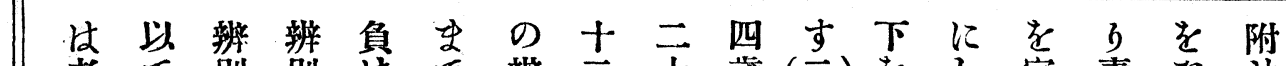

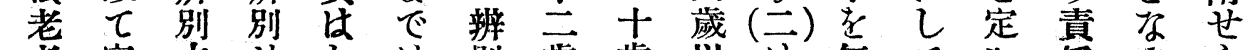

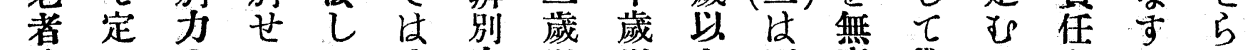

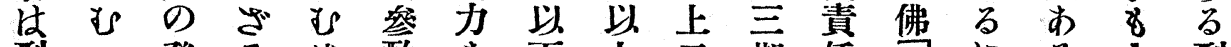
刑

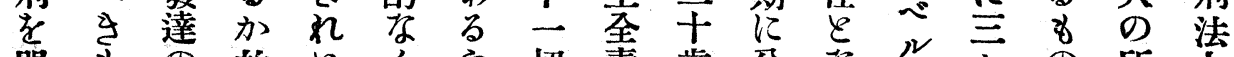

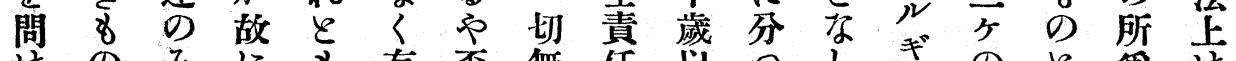

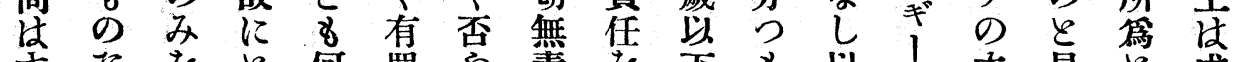

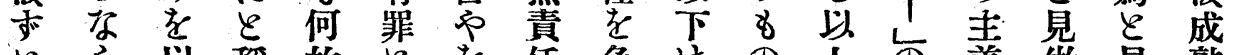
$\varepsilon$ 以程故と往負注の上義做見熟

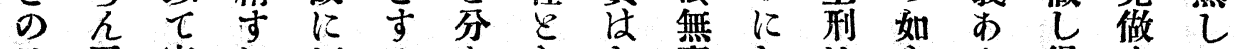

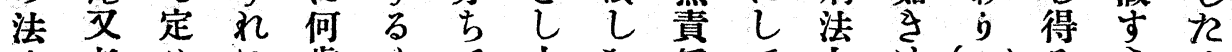

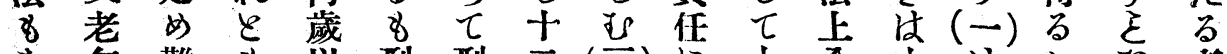

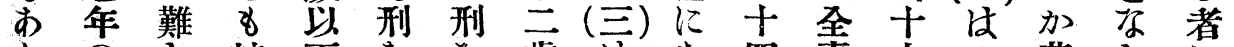

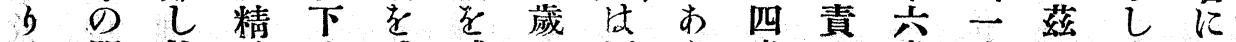

一 $\tau$ 關故神は减减以四ら歳任歲生に生

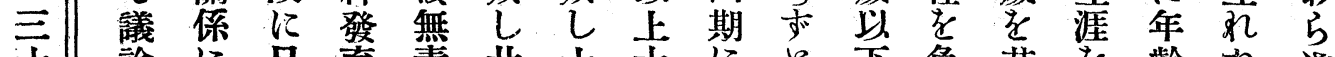

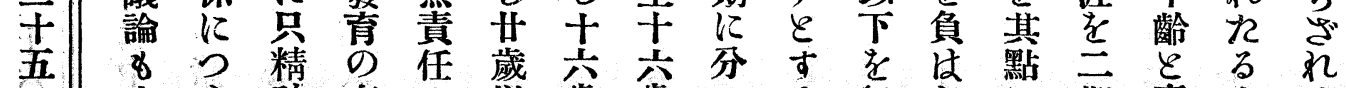

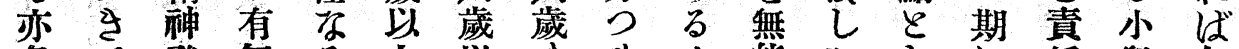

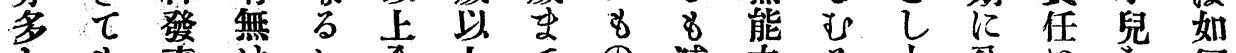

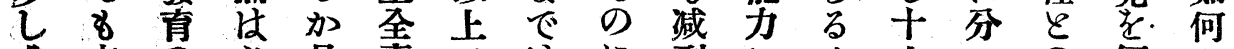
或支 $の$ 必是責毐将飞刑とを亲つの何飞

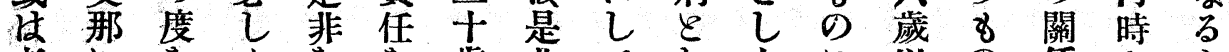

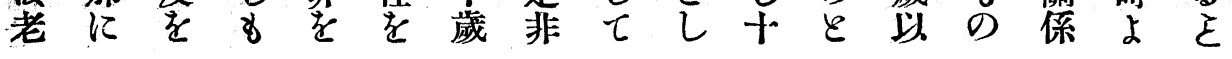




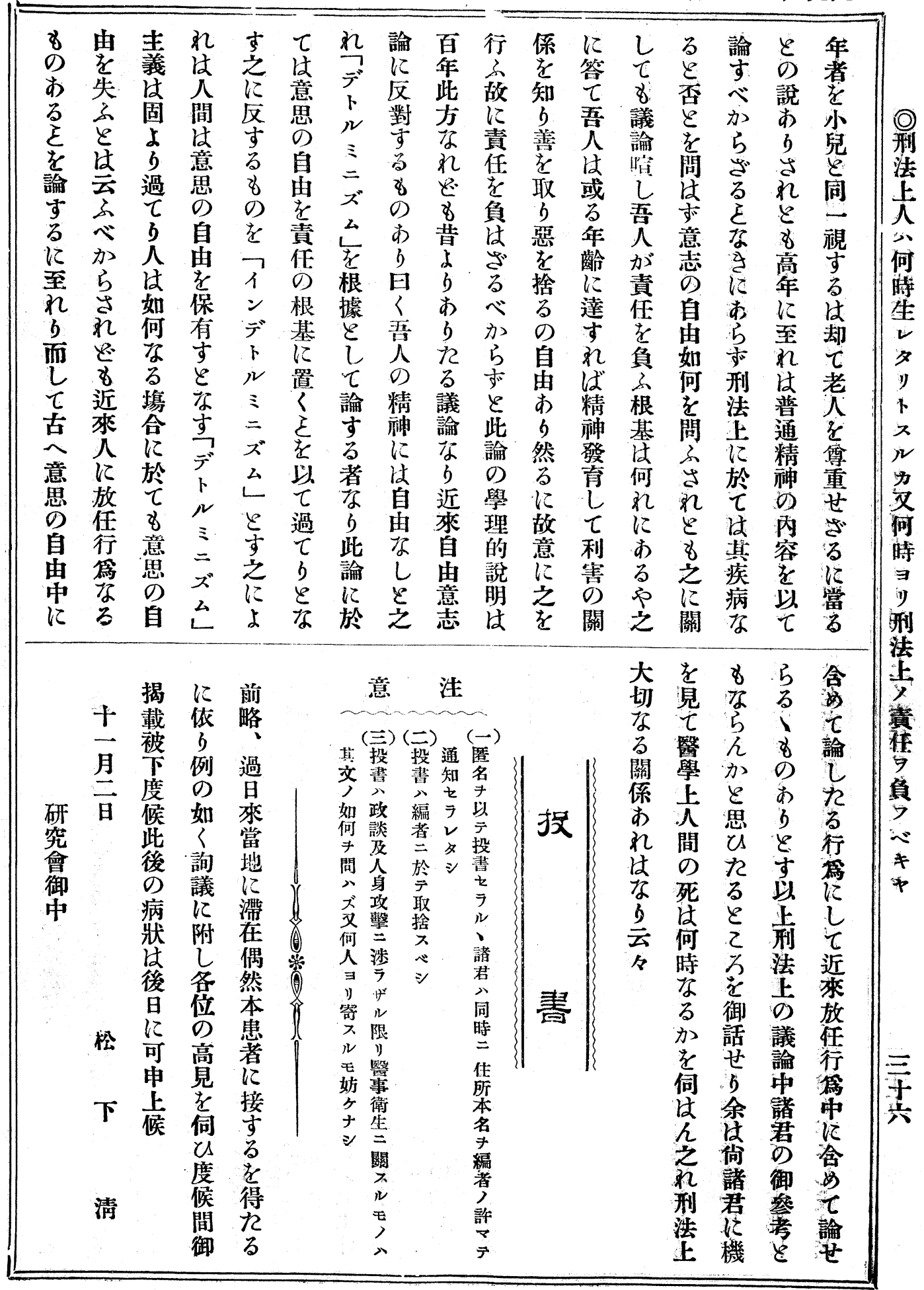

